\title{
TOWARDS A COMPREHENSIVE POSITIVIST THEORY OF LEGAL OBLIGATION*
}

\author{
Kenneth Einar HIMMA
}

Resumen:

El concepto de obligación jurídica es completamente central para la práctica jurídica. Sin embargo, el positivismo carece de una explicación integral de la obligación jurídica, puesto que se concentra solamente en el reconocimiento de obligaciones de segundo orden que recaen sobre los oficiales, y no explican las obligaciones jurídicas de primer orden que recaen sobre los ciudadanos. Cuando las obligaciones jurídicas se relacionan conceptualmente con normas válidas jurídicamente, el error de no tener una explicación integral de la obligación jurídica pone en crisis la teoría positivista de la validez jurídica. En este ensayo se desarrolla la explicación hartiana de la obligación social y se complementa su explicación de las obligaciones jurídicas de segundo orden del oficial en su calidad de oficial con una explicación de la obligación de primer orden de los ciudadanos. Esta última se constituye, argumenta el autor, por la presión social en la forma de la autorización que tiene el Estado de echar a andar la maquinaria coercitiva si no se cumple con la obligación.

* Earlier versions of this paper were presented at the University of Bristol School of Law; the Ono School of Law Conference on Positivism, Democracy and Constitutional Interpretation; the Seminar Problema of the Legal Research Institute of UNAM (National Autonomous University of Mexico); and the McMaster University Conference on the Nature of Law: Contemporary Perspectives. I am indebted to Julian Rivers, Patrick Capps, and Marc McGee for comments and suggestions. I am also grateful to the following for their very helpful comments on earlier drafts of this paper: Larry Alexander, Brian Bix, Patrick Capps, Jules Coleman, Jorge Fabra, Imer Flores, Mark Greenberg, Nina Guzman, Matthew Kramer, Marc McGee, Julian Rivers, Scott Shapiro, Seana Shiffrin, Brian Tamanaha, and Wil Waluchow. 


\section{KENNETH EINAR HIMMA}

\section{Palabras clave:}

Obligación jurídica, validez jurídica, coerción, positivismo jurídico, teoría del derecho.

\section{Abstract:}

The concept of legal obligation is utterly central to legal practice. But positivism lacks a comprehensive account of legal obligation, focusing only on the second-order recognition obligations of officials with no account of the first-order legal obligations of citizen. As legal obligations are conceptually related to legally valid norms, this failure calls into question positivism's theory of legal validity. In this essay, I develop Hart's account of social obligation and supplement his account of the second-order legal obligations of official qua official with an account of the first-order obligations of citizens. The latter is constituted, I argue, by social pressure in the form of the authorization of the state's coercive machinery for non-compliance.

\section{Keywords:}

Legal Obligation, Legal Validity, Coercion, Legal Positivism, Legal Theory. 
Summary: Introduction. I. The Centrality of Obligation Talk to Legal Practice. II. The Concept of Obligation. III. Hart's Theory of Social Obligation. IV. A Comprehensive Theory of Legal Obligation. V. Supporting Considerations.

\section{INTRODUCTION}

Perhaps no concept is more central to legal practice than that of legal obligation. Statutes, case law, and legal arguments are characteristically framed in terms of what some person or class of persons is "obligated" to do. Such practices presuppose that legal norms - at least those making certain actions mandatory - regulate behavior by creating legal obligations. Law characteristically regulates behavior by creating obligations.

Both officials and citizens are subjects of legal obligations. Citizens are obligated to honor their contracts and to refrain from violence under most circumstances; these are first-order obligations defined by primary norms. Judges are obligated to decide cases under the relevant norms; these are second-order obligations (usually) created by recognition norms.

Hart appears to have at least the beginnings of a comprehensive theory of legal obligation. As is well known, Hart believes that legal obligation is a form of social obligation and that social obligations arise when accepted norms are thought sufficiently important to back with social pressure to conform. The second-order legal obligations of officials are explained by their taking the internal point of view towards the rule of recognition. Although he rejected Austin's sanction theory of obligation as not accurately expressing either the sense in which civil law binds or the sense in which officials are bound, he seemed to intimate that first-order legal obligations of citizens are explained by the availability of institutional coercive mechanisms for enforcing first-order legal norms against citizens. As Hart puts 
the point, "the typical form of legal pressure may very well be said to consist in such threats [of physical punishment or unpleasant consequences]" (CL 179, 180).

In this essay, I wish to develop what I take to be Hart's account of social obligation and supplement his account of the second-order legal obligations of official in their capacities as official with an account of the first-order obligations of citizens. The latter is constituted, I argue, by social pressure in the form of the authorization of the state's coercive machinery for non-compliance.

At the outset, it is important to understand that there is a difference between the authorization of coercive enforcement mechanisms and the application of such mechanism in a case of non-compliance. These are two distinct notions. The idea that such mechanism are authorized for non-compliance simply means that officials have authority to use these mechanisms as legally justified responses to noncompliance. The idea that such mechanism are applied simply means that those coercive mechanisms have been used against someone on the ground that he failed to comply. But it is important to note that this does not entail even that the use of such mechanisms are legally justified -as one would expect if legal mistakes are possible. The authorization of coercive enforcement of a legal norm provides a legal justification for the appropriate application of the relevant mechanism for non-compliance with the norm.

One might object that the violation of a legal obligation justifies the application of coercive mechanisms and thus that a legal obligation cannot be constituted by coercive enforcement applications. ${ }^{1}$ This misunderstands the thesis of the paper. The claim being defended here is that the authorization of such mechanisms for non-compliance is, in part, what constitutes a legal norm as binding and hence legally obligatory and thus provides the justification for application in genuine cases of non-compliance. The obligation is constituted, in part, by the authorization of such mechanisms

1 I am indebted to Scott Shapiro for this line of argument. 
and is not identical with the existence or application of such mechanisms.

\section{The Centrality of Obligation Talk to Legal Practice}

The concept of obligation is everywhere in legal practice. For example, a plaintiff in a contract dispute typically claims the defendant is obligated to perform some act, while the defendant argues that the defendant's performance is excused by the plaintiff's own breach of obligation. Likewise, a prosecutor will argue that the defendant breached some obligation or duty defined by the criminal law, while the defense will argue that the defendant did not breach such a duty or obligation. Finally, judges frequently couch their decisions in terms of what some party is obligated to do. In, for example, Henningsen $v$. Bloomfield Motors, Inc., the court held that "[i]n a society ... where the automobile is a common and necessary adjunct of daily life, and where its use is so fraught with danger to the driver, passengers and the public, the manufacturer is under a special obligation in connection with the construction, promotion, and sale of his cars." 2

As these obligations arise under law, they are thought to be legal in source and character. This, of course, is not to suggest that moral obligation is irrelevant to ordinary talk about legal obligation; it is simply to assert ordinary legal talk and practice presupposes the existence of legal obligations analytically distinct from moral obligations. Although the content of law and the content of morality frequently converge, they frequently diverge as well; in such cases, however, the law defines a legal obligation if not a moral one.

The law regulates behavior by a variety of means, including power-conferring norms like those governing the creation of binding contracts and wills, but characteristically

2161 A.2d 69 (1960), at 85 (emphasis added). 
constrains the behavior of citizens by creating such obligations. The law does not generally traffic in weaker "ought"s that encourage behavior without making it mandatory in some sense. Legislative enactments that do not create obligations are not "actionable" and cannot support a claim for damages or punitive measures.

This is the view that Hart takes. Hart observes, for example, that Austin correctly assumes that systems of law necessarily create some legal obligations:

[T]he theory of law as coercive orders, notwithstanding its errors, started from the perfectly correct appreciation of the fact that where there is law, there human conduct is made in some sense non-optional or obligatory. In choosing this starting point the theory was well inspired, and in building up a new account of law in terms of the interplay of primary and secondary rules we too shall start from the same idea. ${ }^{3}$

Further, Hart asserts that it is a conceptual truth that primary legal norms generally define legal obligations (some confer legal liberties): "Rules of the first type impose duties [i.e., primary rules]; rules of the second type [i.e., secondary rules] confer powers, public or private (CL 80-81). If Hart is correct, then law regulates the behavior of citizens by creating obligations that are legal in source and character.

Law is a normative institution and its normativity is conceptually linked to its capacity to generate obligations. This suggests an adequacy constraint on conceptual theories of law. While conceptual theories of law are most conspicuously concerned with giving an analysis of the concept of law, they must also be concerned to provide an account of all normative concepts figuring prominently in legal practice -including that of legal obligation.

3 H. L. A. Hart, The Concept of Law, Rev. ed. (Oxford: Oxford University Press, 1994), 82; emphasis added. Hereinafter $C L$. 


\section{The Concept of OBLIGATion}

If ordinary talk is any indication, there are different types of obligation. We distinguish, for example, moral, social and legal obligations and speak as if these types of obligation are conceptually distinct. Even so, many theorists believe they are instances of the same general type. As Joseph Raz puts it: 'normative terms like 'a right', 'a duty', 'ought' are used in the same sense in legal, moral, and other normative statements." 4 While moral, social, and legal obligation differ in important ways, there are certain elements essential to the notion of obligation and these elements are present in moral, social, and legal obligations.

This is certainly true of various kinds of norm. For example, moral and legal norms are conceptually distinct; the content of moral norms sometimes diverges from the content of legal norms, as is presumably true of the content of the moral and legal norms governing promise-keeping. But moral and legal norms are both kinds of norm; as such, they instantiate properties that are necessary and sufficient for being "norms." Although legal and moral norms have many different properties, both satisfy the application-conditions for the concept-term "norm."

One would expect, as Raz believes, that the same would be true of the various kinds of obligation. Legal and moral obligations presumably have different properties, but both satisfy the application-conditions for the concept-term "obligation" in the following sense: satisfaction of the application-conditions for "obligation" will be necessary (though not sufficient) for something to count as either a "legal obligation" or a "moral obligation". If so, then the set of application-conditions for "obligation" will be a subset of the set of

4 Joseph Raz, The Authority of Law (Oxford: Clarendon Press, 1979), 158. See also Richard Brandt, "The Concepts of Obligation and Duty," Mind p. 380 ("[I]t is dubious whether there are sharply distinct moral and non-moral senses [of 'obligation']. It may be that 'obligation' and 'duty' preserve an identical core of meaning throughout moral and non-moral uses. This, in fact, is the view of the matter best supported by the evidence.") 
application conditions for "moral obligation" and "legal obligation".

If this is correct, then we cannot understand the concept of legal obligation without understanding the general notion of obligation. ${ }^{5}$ In what follows, I will sketch what I take to be the central elements of the general concept of obligation.

\section{Obligations and Mandatory Prescriptions}

It is tempting to think that this much is clear about obligations: obligations are conceptually related to norms. While the existence of a norm prescribing act $X$ might not be a sufficient condition for $X$ to be obligatory in the relevant sense, it is a necessary condition. There simply could not be an obligation unrelated (perhaps in the strong sense of being defined by) to a norm.

Although plausible, the idea that the existence of a norm prescribing $\mathrm{X}$ is a necessary condition for someone to be obligated to $\mathrm{X}$ is problematic for the following reason. It cannot be applied to morality without assuming a substantive account of morality that is controversial — namely, the idea that morality is grounded in general norms. Moral particularists deny this assumption, believing that the morality of any particular behavior is too context-dependent to be captured by general norms - even those that state, so to speak, their own

5 Hart was concerned with analyzing the concept of obligation - though he focused on social obligation, apparently believing that all obligations are social in character: (1) "[I]t is crucial for the understanding of the idea of obligation to see that in individual cases the statement that a person has an obligation under some rule and the prediction that he is likely to suffer for disobedience may diverge"; (2) "It is clear that obligation is not to be found in the gunman situation, though the simpler notion of being obliged to something may well be defined in the elements present there"; (3) "To understand the general idea of obligation as a necessary preliminary to understanding it in its legal form, we must turn to a different social situation which, unlike the gunman situation, includes the existence of social rule; for this situation contributes to the meaning of the statement that a person has an obligation in two ways"; (4) "The statement that someone has or is under an obligation does indeed imply the existence of a rule"; and (5) "Rules are conceived and spoken as imposing obligations when the general demand for conformity is insistent and the social pressure brought to bear upon those who deviate or threaten to deviate is great" ( $C L$ 85-86; emphasis added). 
exceptions; however, particularists are not skeptics about morality or about the idea that we have moral obligations. A theory that purports simply to articulate the content of the general concept-term "obligation" should not have controversial substantive implications about morality.

What we can say, however, is that obligations are associated with prescriptions, which include claims - claims about what someone (or some class of persons) ought to do in some state of affairs - and norms. Obligations arise only where there are prescriptions that guide and enable the appraisal of human acts. If I have an obligation to do $A$ at $t$, then there is some prescription that either expresses or implies that I ought to do $A$ at $t$. That is, it is a necessary condition for someone's being obligated to perform some act that there is a prescription that expresses an obligation owed by that person to perform that act.

Not every prescription expresses or implies an obligation. Although all prescriptions purport to commend some behavior (or abstinence), not all prescriptions require them; there are things I ought to do that I am not obligated to do. There are, for example, prudential norms that, other things being equal, express the idea that one ought to exercise regularly, but those norms do not create or express obligations because prudential norms are prescriptive but do not create "requirements" or "obligations" in any meaningful sense and therefore could not be "mandatory" in the relevant sense. The only prescriptions that create or express obligations are mandatory prescriptions -i.e., prescriptions that require some act.

It therefore appears to be a necessary condition for $P$ to be obligated to do $a$ that there is a mandatory prescription that requires that $P$ do $a$. If there is no mandatory prescription requiring $a$, then there is no obligation to perform $a$; the claim that $a$ is obligatory but not required by a mandatory prescription seems self-contradictory. Obligations are thus correlated with mandatory prescriptions. 


\section{Obligations as Reasons}

Obligations are commonly thought to correlate with reasons. On this view, the claim that $\mathrm{X}$ has an obligation to do $a$ implies that $\mathrm{X}$ has a reason to do $a .{ }^{6}$ If $\mathrm{Y}$ asks $\mathrm{X}$ for a justification for X's doing $a$, "X was obligated to do $a$," if true, is always relevant in assessing whether doing $a$ was justified from the standpoint of practical rationality.

The reason can be moral, but need not be. Some obligations are associated with moral reasons but not all obligations are. If, as many theorists believe, it is not true that the status of a norm as law does not afford a prima facie moral reason to obey it even in reasonably just states, then it is reasonable to think that one does not have even a prima facie moral reason to obey wicked laws that create legal obligations. There are clearly other kinds of reasons, such as prudential -although the number of different types of "basic" reason (i.e., reasons that are irreducible to other reasons) are limited.

Indeed, it is very difficult to think of any other basic reasons than prudential and moral reasons. Perhaps there are aesthetic reasons as well. But if there are no other basic reasons, then every other kind of reason, including legal reasons, will ultimately be "compound" in character, ultimately constituted by some combination of members of the set of basic reasons.

The reason might be conclusive, but it need not be. It seems that, as an objective matter of practical rationality, we have a conclusive reason for doing what we are morally obligated to do all things considered. I have a reason not to torture another innocent person no matter what else might be true and hence a conclusive reason for not doing so. But whatever prudential reason Nazis may have had to do mor-

6 Not everyone accepts this view. For example, Scott Shapiro believes that obligations merely purport create or be reasons. On his view, there can be obligations that neither create nor are identical to reasons. The argument of this paper, however, depends on the denial of this view, which I cannot defend here. 
ally wicked things, it was clearly not conclusive; taking into account the relevant moral reasons, they had a conclusive reason not to do these things.

If ordinary talk is any indication, obligations are reasons. ${ }^{7}$ Again, it is always a relevant consideration in justifying the performance some act $a$ or, relatedly, in deliberating whether to do $a$ that one has an obligation of some kind to do $a$. "Because I had an obligation to do $a$ " might not be an adequate answer to the question "why did you do a?"; it might be false that I had an obligation to do $a$ or it might be true that I had such an obligation, but it was outweighed by some a more important obligation. But if, as seems reasonable, only reasons can practically justify an act, then obligations are reasons. Genuine obligations are necessarily normative and hence are reasons for action.

\section{Obligations as Exclusionary}

Obligations are defined by valid mandatory prescriptions, and mandatory prescriptions are fairly characterized as "exclusionary" in this respect: A's desires and prudential interests are generally irrelevant with respect to whether A should perform an act required by a mandatory prescription. If $\mathrm{A}$ fails to do $p$ and $p$ is required by a mandatory prescription, it is not a justification, other things being equal,

7 It is worth noting here that ordinary talk about law (and the corresponding legal practices) presuppose that one can have a reason independent of one's mental states, which is incompatible with reasons-internalism. According to the internalist, there are no reasons that are external to the agent's mental states; an agent has a reason for doing $\mathrm{P}$ if and only if the agent instantiates the appropriate mental state - usually a belief-desire pair. While the assumption that internalism is false is controversial, I am concerned with giving a conceptual account that harmonizes with our ordinary law talk and legal practices, which presupposes that there are other kinds of reasons than simply the belief-desire pairs. Ordinary talk does not imply the denial of such reasons but characterizes such reasons as subjective. Ordinary talk and legal practice seem to presuppose that moral and legal reasons are objective in character. Internalism would entail something like an error theory of law. That might ultimately be correct, but it takes an argument to establish that. 
that A did not want to do $p$ or that doing $p$ did not conduce to A's interests. ${ }^{8}$

This characteristic of obligation is also related to the concept of wrongness. An act is wrong if and only if it is not justified or excused (one justification would be, of course, that the behavior is permissible). Mandatory prescriptions, as a conceptual matter, exclude certain kinds of justifications for non-performance, and it is the exclusion of these stories as not constituting valid reasons for non-performance that helps to explain why the relevant acts are properly thought of as mandatory or required: an act that people are generally free not to perform because it is trivially justified under a prescription is not required by the prescription.

The claim here is that, as a conceptual matter, the reasons for doing $p$ do not depend on its satisfying our own particular prudential interests is entailed by the core of what we mean when we say $p$ is required by a valid mandatory prescription. The claim $p$ is required by a mandatory prescription $N$ is inconsistent with the claim non-performance of $p$ can be justified under $N$, as a general matter, by purely prudential considerations - in much the same way that the claim that $p$ is a bachelor is inconsistent with the claim that $p$ is married. Obligations that are defeasible by reference to anyone's prudential interests, no matter how trivial, is as incoherent as the idea that some bachelors are married. 9

Although the term "exclusionary" is sometimes thought to be synonymous with the Razian notion associated with

8 This, of course, draws heavily on Joseph Raz's influential Practical Norms and Reason (Princeton, 1990).

9 It is worth noting that the claim that obligations are exclusionary reasons logically entails that there are no prudential obligations. A prudential obligation would be a prudential reason - indeed, a very strong one - that excludes prudential reasons as a justification for non-performance of an obligation, an implication that appears to be logically incoherent. A prudential obligation would require one to do what one has most prudential reason to do and hence could not exclude prudential considerations as justifying non-performance. This strikes me as the correct result: we talk of the victim of a robber as being obliged, rather than obligated, to comply - at least in the absence of other factors such as responsibility to his or her family. 
the term "pre-emptive reason," they are not synonymous as defined above. A Razian pre-emptive reason has a certain structure consisting of a first-order reason to do (or not do) some act and a second-order reason not to act on one's assessment of the first-order reason. The idea that mandatory prescriptions are exclusionary claims or presupposes nothing about the structure of the relevant reasons, and hence does not assume that obligations give rise to second-order reasons. The claim is merely that a mandatory prescription is exclusionary in the limited sense of excluding certain stories as justifying or excusing non-performance.

\section{The Special Normative Force of Obligations: Obligations as Binding}

The concepts of obligation and wrongness are related to the concept of being (normatively) bound. Obligation-talk is frequently couched in terms of a relationship in which the subject of the obligation is bound to the norm. As Hart puts the point, "The figure of a bond binding the person obligated ... is buried in the word 'obligation"' (CL 87). Obligations, according to ordinary intuitions, bind us.

In what sense? The term "must" (and, less frequently, the term "shall") is frequently used to express that we have an obligation - and are hence bound - to perform some act. We may do what is permissible and should do what is good, but we must do what is obligatory.

It might be tempting to explain the concept of bound in terms of some sort of psychological or physical compulsion. The idea here is that persons are bound by a rule creating an obligation in the sense that they are psychologically or physically "unfree" to do other than what the rule requires. But not every obligation, as a conceptual matter, is supported by compulsion of this kind. Many persons do not feel psychologically compelled (i.e., psychologically unfree) to satisfy moral obligations. Further, there are many obligations not supported by physical compulsion; we are not physically compelled (i.e., unfree in some physical sense) not to lie. Here 
coercion and compulsion, it should be remembered, are two different things: a gunman coerces me with the threat of death but, other things being equal, cannot compel me to obey.

It might also be tempting to think that the exclusionary character of obligations (or mandatory norms) is enough to explain the binding quality of obligations but, as that concept has been explained in this paper, the exclusionary character of obligations, by itself, lacks the resources to explain the binding quality of obligations. The claim that a mandatory norm is exclusionary says something about its content or; that is, it expresses the idea, as we have seen, that the content of the norm is such that it disqualifies certain stories as justifying non-performance. But the claim that a mandatory norm binds us is a claim about its normative force; this is the point of the metaphor of a bond that ties us to rule (i.e., the normative force binds us to the rule). ${ }^{10}$ Simply knowing that the content of a norm excludes certain considerations as justifying non-performance does not tell us much, if anything, about the nature of this bond or the special normative force that it has. Indeed, it doesn't even tell us whether a norm that functions this way has any normative force because it tells us nothing about whether the norm is valid or applicable. Invalid mandatory norms are exclusionary in this limited sense, but they have no normative force and hence do not bind.

\section{HART'S THEORY OF SOCIAL OBLIGATION}

Legal obligation, as conceived by Hart and most positivists, belongs to a special class of obligations. Since positivism explains law as a set of social practices, the concept of

10 Of course, as Raz defines the term, exclusionary reasons are capable of binding. See Joseph Raz, Engaging Reason (Oxford: Oxford University Press, 2000). I have not adopted the Razian account here because it is not obvious to me that it is a conceptual truth that legal obligations are exclusionary reasons in this sense Although it seems clear that moral reasons are such reasons, it is not clear that very wicked legal norms would generate a robustly exclusionary reason. I think most theorists would concede no more than that law "purports" to create exclusionary reasons in the stronger sense intended by Raz. 
obligation applicable in legal practice must itself be explicable in terms of social practices. Legal obligation, then, is a species of social obligation. ${ }^{11}$ A full explanation of the concept of legal obligation, then, requires an explanation of the concept of social obligation, which must harmonize with the explication of the general concept of obligation. Hart's account of social obligation is developed below.

\section{Social Prescriptions}

The first element is straightforward. Although not every social norm gives rise to a social obligation (e.g., some create social powers), social obligations arise under general social prescriptions - or social norms, which are created, as Coleman puts it, by a convergence of attitude and behavior. Persons in the group converge on taking the internal point of view towards the norm, accepting it as a standard that governs the behavior of people in the group, and generally conform to its requirements. Thus, if people in the group (1) self-consciously accept the norm (this need not be for moral reasons); (2) generally conform to the norm; and (3) take a critical reflective attitude toward the norm using it to evaluate the behavior of other members of the group, then it is, on Hart's view, a social norm governing behavior in the group.

\section{Acceptance and Exclusionary Norms}

Taking the internal point of view towards a mandatory norm, on Hart's view, involves regarding oneself and others in the relevant group as being obligated by the rule. Acceptance of such a norm involves some sort of durable commitment to subject one's own behavior to governance of the rule and to evaluate the behaviors of other people according to the rule. Someone who genuinely commits to subjecting

11 It is unlikely that social obligations create social reasons that are basic (or irreducible) in character. See note 7 , above. 
her behavior to the rule will accept and participate in a host of normative practices regarding the rule -including practices that treat members of the group, including herself, as obligated. Someone who accepts a rule defining an obligation will surely regard herself as being obligated by the rule.

This suggests that persons who accept a mandatory social norm will accept it as a reason for complying with and treat it as being exclusionary in the sense described above. A mandatory norm is exclusionary in character in the sense that it excludes certain justifications for non-conformity, but this does not imply that any particular person does treat or should treat the rule as what Raz calls a pre-emptive reason in her deliberations. Insofar as the person who accepts the mandatory social rule will treat it as a reason of some kind. But someone who accepts a mandatory social norm and conceives it as an exclusionary reason might -but need not - treat the norm as a pre-emptive reason in her deliberations about what to do. Moreover, if accepting a rule gives one a reason for following it (for as long as one accepts it), such a person has a reason for treating the norm as exclusionary -at least for as long as she accepts the rule.

\section{How Social Obligation Binds}

While unilateral acceptance alone can explain a person's adoption of a social norm as functioning as exclusionary, unilateral acceptance, by itself, cannot explain the normative force of the obligations to which social norms give rise. After all, unilateral acceptance can always be given and withdrawn at will, and if that is all there is to the story, it is hard to see how a durable social obligation could arise. What explains the binding (and hence durable) quality of a social obligation owed by a member of the social group is, in part, the attitudes of other members of the social group towards non-compliance. 
Hart explains the binding character of social obligations in terms of considerations ordinary persons are likely to regard as having normative significance. According to Hart, "[r]ules are conceived and spoken of as imposing obligations when the general demand for conformity is insistent and the social pressure brought to bear upon those who deviate or threaten to deviate is great" (CL 85-86). ${ }^{12}$ Social pressure in the form of a hostile reaction is something people with ordinary psychological characteristics tend to regard as having normative force. Not everyone responds in the same way to (or cares as much about) social disapproval, but it is an empirical fact that ordinary persons tend to dislike criticism and hostility and are willing to take at least minimal steps to avoid it.

A couple of points deserve attention. First, deviating behavior under the norm is generally regarded as a reason or justification for the application of social pressure. The claim is not just that, as a general matter, deviating behavior correlates with social pressure. Rather, it is that members who accept the rule regard the rule as a reason for applying social pressure: "For [those who take the internal point of view towards a rule], the violation of a rule is not merely a basis for the prediction that a hostile reaction will follow but a reason for the hostility" (CL 90). This will be true, as a conceptual matter, for any form of social obligation, on Hart's view, including legal obligation.

Second, the claim is not that social pressure is sufficient for social obligation; after all, the gunman exerts social pressure on his victim. Rather, it is that a convergence of attitude and behavior on a rule, together with the appropriate kind of social pressure, constitutes the norm as obligatory. Such pressure is likely supported by a belief that it is warranted (though not necessarily morally warranted),

12 Such social pressure "may take only the form of a general diffused hostile or critical reaction" (CL 86), but may also rise to the level for "physical sanctions" (CL 86); in this latter case, the rules are properly regarded as a "rudimentary" or "primitive" form of law (CL 86). 
which is related to two factors: (1) the acceptance of the social norm; and (2) the belief that the norm is important because "necessary to the maintenance of social life or some highly prized feature of it" (CL 87).

Hart's explanation of social obligation can be summed up as follows:

Hartian Theory of Social Obligation (HTSO): $X$ has a social obligation to do $p$ if and only if (1) members of the relevant group converge in attitude and behavior on a norm $N$ governing $X$ that requires $X$ to do $p$; and (2) $N$ is supported by significant social pressure and (3) because $N$ is thought important because necessary to the maintenance of social life or some highly prized feature of it.

According to HTSO, it is the presence of the appropriate social pressure in a context that includes the existence of a practice along with certain beliefs about the importance of the norm that explains the sense in which the obligation is, as a conceptual matter, binding: "social pressure appears as a chain binding those who have obligations so that they are not free to do what they want" (CL 87). No matter how important a social norm $N$ might be thought by relevant members of the group, it is incorrect to characterize it as defining an obligatory and hence binding requirement if not supported, in some way, by the appropriate level of social pressure. As Hart puts the view, such pressure is the "primary" characteristic of obligation (CL 87).

This implies neither that every person feels the force of the social pressure that makes a social norm binding nor that any person should feel this force. The claims here are quite limited. They are purely descriptive because they make no claims about what people should regard as reasons. Further, they make no claim about what any particular person in a social group might feel in response to social pressure; as Hart points out, "there is no contradiction in saying of a hardened swindler ... that he had an obligation to pay the rent but felt no pressure to pay" (CL 88). The assumption is significantly weaker: as an empirical matter, 
people tend to care about social pressure enough to modify their behavior in many circumstances.

One might be tempted to interpret Hart's remarks on social pressure and social obligation as making the weaker claim that social pressure signals that people in the group regard the norm as obligatory, rather than the stronger claim that it contributes to constituting the norm as obligatory. I think this is mistaken for two reasons. First, Hart clearly takes himself as giving an analysis of the concept of social obligation: "To understand the general idea of obligation as necessary preliminary to understanding it in its legal form, we must turn to a different social situation which, unlike the gunman situation, includes the existence of social rules; for this situation contributes to the meaning of the statement that a person has an obligation in two ways" (CL 85). The elaboration of the idea that social pressure supports social obligation occurs two paragraphs later. Second, Hart rejects Austin's view largely on the strength of the gunman example. It would be uncharitable in the extreme to construe Hart as lacking a theory of social and legal obligation when he rejects Austin, in part, on his perceived failure to provide a satisfactory account! Finally, Hart himself is clear in thinking that an analysis of the concept of legal obligation is foundational to a conceptual theory of law: for example, he writes, "It will be recalled that the theory of law as coercive orders notwithstanding its errors, started from the perfectly correct appreciation of the fact that" - and it should be clear that this is a metaphysical claim about law- "where there is law, there human conduct is made in some sense non-optional or obligatory" (CL 82).

\section{A Comprehensive Theory of Legal Obligation}

\section{Second-order Legal Obligation as Defined} by a Social Rule of Recognition

Ultimately, there are two conditions, on Hart's view, necessary and sufficient for the existence of law and legal obli- 
gation. First, officials converge in taking the internal point of view towards and conforming to a conventional rule of recognition. Second, citizens generally comply with the rules validated by the conventional rule of recognition. First- and second-order mandatory norms in such a system define legal obligations.

The idea that officials take the internal point of view towards the rule of recognition suggests that they accept and treat it as an exclusionary reason in assessing their own and other officials' behavior. Like all forms of obligation, legal obligations are exclusionary in the sense that certain stories are disqualified as excuses or justifications for non-compliance; this is just true in virtue of what it means for a behavior to be "required by a mandatory norm". But insofar as officials accept the rule as a standard governing their behavior, they regard it as a reason and have a disposition to treat the rule as exclusionary in character.

It is important to recall here that Hart does not argue that it is unilateral acceptance that binds an official to the rule of recognition; that would be problematic because unilateral acceptance does not provide anything that necessarily has independent normative force given what we know about the psychology of ordinary persons. Hart argues instead that it is the joint acceptance by officials together with social pressure on each to conform to the rule of recognition that together warrant characterizing the rule of recognition as being "obligatory".

Such pressure is likely to have normative force for officials because they can be presumed to care about what other officials think. Voluntary membership in a social group governed by norms signals that the member regards at least some of the beliefs and actions of the other group members as having significant motivational force. It is, thus, reasonable to think that someone who seeks out membership in a social group, at least if their motivations are sincere and non-subversive, will regard such pressure to conform as having significant motivational force. 
This does not imply that the motivation for conforming to a social norm must be explained in terms of a desire to avoid the social pressure. ${ }^{13}$ I assume that most people want to avoid the condemnation accompanying a murder conviction and hence regard the prospect as having motivational force -and this includes people who commit murders. But the motives that explain why most people do not commit murder make no reference at all to these prospects. What explains why most people do not commit murder is, in part, a subjective moral reaction to murder (any decent person would be horrified at the thought of committing such an act) and a lack of extreme anger and hostility.

The point of these sorts of social mechanisms in Hart's analysis, then, is not to explain why officials accept the rule of recognition. Officials who take the internal point of view towards the rule of recognition are presumably motivated to conform to the rule by whatever desires brought them to officialdom to begin with. While officials would also presumably want to avoid the disapprobation of other persons in the relevant groups, Hart is not committed to explaining their behavior in terms of some necessary motivation to avoid such social pressure. Social pressure explains how the rule of recognition obligates, and not why officials accept this rule.

\section{Second-order Obligation as Explanation of First-order Citizen Obligation}

Hart's theory of second-order obligation will not explain first-order legal obligation. Merely showing that officials can obligate themselves through some mechanism does not show that their acts qua officials can obligate citizens. The claim that you and I have obligated ourselves to behave in a

13 As Hart puts this important point, "[t]he fact that rules of obligation are generally supported by serious social pressure does not entail that to have an obligation under the rules is to experience feelings of compulsion or pressure" (CL 88). 
particular way does not entail any claim about the obligations of other people.

Whether officials can obligate citizens depends, in part, on to whom the officials owe their obligations. If the officials' obligations under the rule of recognition are owed to citizens, then it is reasonable to think that citizens are obligated by the norms valid under it. Given the logic of obligation, it is hard to make sense of the idea that a judge owes an obligation to all citizens to incarcerate citizens who violate norm $N$ if $N$ does not obligate citizens. It would be odd if the concept of legal obligation behaved this way.

But Hart's practice theory implies only that the obligations owed by group-members are owed to other members. Hart has nothing that would explain how obligations binding members of the group could be owed to anyone outside it; there is nothing in the practice theory as it explains the obligations of officials that entails that the obligation is owed to citizens. All the theory claims is that officials owe these obligations to one another —and this says nothing that would justify thinking official acts obligate citizens.

Of course, non-members might be obligated to follow rules of groups to which they do not belong. Non-Muslims are required to abide by certain conventions that Muslims have accepted regarding behavior inside mosques, but this is explained by other standards to which non-Muslims are subject; non-Muslims have a duty to respect those conventions when in mosques. Since admission to mosques is conditioned on consent to abide by certain standards, one shouldn't enter a mosque unless prepared to abide by the relevant standards.

\section{Coercive Enforcement and First-order Legal Obligation}

Once law is explained in terms of a social rule of recognition accepted by officials in an efficacious legal system, citizen obligation in modern municipal legal systems seems 
best explained in terms of the authorization of formal institutional mechanisms of coercive enforcement. The idea here is not that coercive enforcement of a norm, by itself, constitutes the norm as obligatory; rather, it is that coercive enforcement of a social norm in a system that satisfies certain properties -including the institutionalization of the relevant set of norms - constitutes it as legally obligatory. Coercive enforcement of a legal norm constitutes it as legally obligatory upon citizens, in part, because (1) the norm belongs to an institutionalized system of norms (2) grounded in recognition norms accepted and practiced by officials and is (3) minimally efficacious in regulating citizen behavior.

Here it is important to emphasize the normative dimension of this practice. While officials of the legal system need not regard a first-order law as a moral justification for enforcing the law against non-compliance, they regard it as a legal reason or justification (i.e., a reason that is internal in the sense that it is within the system of law) for such enforcement. Obligation is explained by a normative web of practices that includes the legal authorization of formal enforcement mechanisms as a legal justification for applying them to citizens for non-compliance.

Formal institutional enforcement should be distinguished from sanctions. Enforcement sometimes involves punitive intent, as it does in the case of a defendant who is being prosecuted for murder under the criminal law. But it need not involve such intent, ${ }^{14}$ as in the case of a judge ordering damages for breach of contract. ${ }^{15}$ Such enforcement mech-

14 It is worth noting that Austin is careful to point this out: "Considered as thus abstracted from the command and the duty which it enforces, the evil to be incurred by disobedience is frequently styled a punishment. But, as punishments, strictly so called, are only a class of sanctions, the term is too narrow to express the meaning adequately" (PJ 22).

15 As natural law theorist John Finnis puts it: "Not all lawful coercion is by way of sanction or punishment. Even the most developed legal systems rightly allow ... the arrest of certain suspected offenders or potential offenders, and of persons and things (e.g. ships) likely otherwise to escape due process of adjudication. Judgments may be executed, and some other classes of debts satisfied, by seizure, dis- 
anisms include sanctions but also include the court's power of contempt, which backs every court order. Moreover, the court's authority over these mechanisms includes the authority to refuse to enforce or recognize a defective instrument of some kind, which might include a contract, will, or even a statute. Refusal to enforce a defective contract is part of how courts coercively enforce the laws governing formation of a contract.

What constitutes a mandatory norm as legally obligatory in modern municipal legal systems is that coercive enforcement is legally authorized. If the application of coercive force for violations of a valid legal norm $N$ is authorized by some valid legal norm as a normative response to nonfeasance, then $N$ is legally obligatory and its binding force is constituted by the authorization of the relevant coercive mechanisms. Of course, it is probably true that it is also a necessary condition for the existence of a legal obligation is that the application of the relevant coercive mechanisms are reliably applied in cases where they are authorized. But this is not part of what constitutes a norm as legally obligatory.

\section{Supporting Considerations}

\section{The Centrality of Coercive Enforcement in Modern Judicial Practice}

The availability of formal, institutional coercive enforcement mechanisms is a central feature of law in modern municipal legal systems. Most obviously, the criminal law is characteristically backed with punishment. But such mechanisms also play a central role in civil law: the point of bringing a civil lawsuit is to get a court order requiring the defendant to do something. Sometimes the plaintiff seeks damages; sometimes the plaintiff seeks specific perfor-

traint, forced sale". Finnis, Natural Law and Natural Rights (Oxford: Clarendon Press, 1980), 261. 
mance. However, any plaintiff who brings a civil suit in any legal system remotely resembling this one is asking the court not only for a judgment, but also a court order.

The court has authority to enforce its lawful orders by a formal, institutional coercive mechanism known as the contempt sanction. It is this power that enables the judge to enforce her orders in civil cases where they cannot plausibly be characterized as imposing direct or indirect sanctions. In systems like ours, every court order is backed by the legal authorization of the contempt sanction for non- compliance.

This suggests that coercion is central to legal systems resembling that of the U.S. Since the contempt sanction is both coercive and universally available to courts to enforce its orders in civil and criminal matters, it follows that every criminal and civil law is ultimately backed with a coercive mechanism (since the court's contempt sanction is coercive). The authority of the court to issue coercively enforced orders is foundational to its ability to decide disputes in systems like this one.

At the very least, this much seems reasonable: in cases where (1) formal coercive mechanisms are generally authorized for non-compliance and (2) officials lack authority to apply these mechanism in enforcing a particular judgment, norm, or order with coercive mechanisms, it is implausible to characterize the judgment, norm, or order as "obligatory". Such norms are more fairly characterized as "advisory" because there is no sense in which the relevant behavior is made mandatory by mechanisms reasonably presumed to have normative relevance given human beings as we understand them. ${ }^{16}$

This is not to suggest that legal obligation cannot exist in a legal system without formal, institutional coercive mechanisms, which would entail that such mechanisms are a

16 This should not be understood as implying that legal reasons are purely subjective belief-desire pairs. At most, it presupposes that objective reasons, if such there are, are capable of functioning as subjective reasons in our practical deliberations given what we know about our psychological characteristics. 
conceptually necessary feature of law - that is to say, that law is necessarily coercive. For purposes of this paper, I am agnostic with respect to whether there could be a system of law in normative systems where only informal social pressure is available as a coercive mechanism. I tend to think that law is necessarily coercive in this respect but nothing in the argument here should be construed to presuppose that view. Although the Hartian account of social obligation, as I have construed it, entails that social pressure is a necessary condition for social obligation, the account of legal obligation here assumes only that some form of social pressure is a necessary condition for legal obligation. The specific view that the authorization of formal, institutional coercive mechanism constitutes the binding force of obligation applies only to modern municipal legal systems like that of the U.S. ${ }^{17}$

In any event, the authorization of such measures is a more reliable indicator of a legal obligation than the language in which the relevant law is expressed. A statement asserting that the defendant "must" or "shall" perform some act is, despite its language, best characterized as "advisory" if no coercive legal consequences are authorized for failure to comply. ${ }^{18}$ Further, a statute asserting that people "should" perform some act is, despite its language, best characterized as "obligatory" if courts are authorized to incarcerate people who do not perform the act.

As a general matter, officials are quite careful to ensure that the words of an authoritative statement of law adequately signal whether coercive enforcement mechanisms are available, but this is explained by non-conceptual con-

17 Nor is it to suggest that the coercive mechanisms must be applied by an agency that is part of a legal system. As a conceptual matter, the prison system could be privatized, for example, without altering the status of an institutional system of norms as a legal system.

18 There are, of course, some laws that authorize sanctions but are chronically unenforced. Whether or not these count as legally obligatory will be determined by whether they count as valid under that system's recognition practices. In some legal systems, the chronic failure to enforce or apply a norm suffices invalidate the law, a situation sometime described as "repeal by desuetude." 
siderations. Conscientious officials want to ensure that authoritative statements of law convey appropriate notice of what is required. The terms "must" and "shall," in contrast to "should" and "ought," signal that some behavior is required and provide constructive notice to citizens that courts have recourse to some coercive mechanisms - though such terms do not say anything about the nature or severity of such mechanisms.

Still, it is the availability or non-availability of coercive mechanisms, and not the language in which a rule of law is expressed, that ultimately determines whether that rule defines a legal obligation. When the language in which a legal norm $N$ is expressed and the availability of coercive enforcement mechanisms do not agree, it is the latter that determines whether $N$ is fairly characterized as "legally obligatory" upon citizens.

\section{Is Coercive Enforcement a Conceptually Necessary Feature of Law?}

Many theorists believe that coercive enforcement is a conceptually necessary feature of law. Natural law theorists frequently acknowledge the central role coercion plays in law. John Finnis, for example, observes that "[1]aw needs to be coercive (primarily by way of punitive sanctions, secondarily by way of preventive interventions and restraints)". Likewise, Ronald Dworkin believes the conceptual function of law is to justify the state's use of its police power and hence that the law includes the moral principles that show statutory and judicial law in their best moral light. Further, positivists, like Joseph Raz, also acknowledge the centrality of coercion in law: "The three most general and important features of the law are that it is normative, institutionalized, and coercive."19

\footnotetext{
19 Joseph Raz, The Concept of a Legal System, 2nd ed. (Oxford: Clarendon Press, 1980), 3. Hereinafter CLS. Raz has changed his view on this issue. See Raz, Practical Norms and Reason (Princeton: Princeton University Press, 1990).
} 
Intuitively, there is something to be said for this view. No matter how closely it might resemble societies with legal systems, a "society of angels" with rules promulgated under a rule of recognition does not seem to have "law" if these rules are not subject to coercive enforcement; such a society seems utopian and as having transcended law. ${ }^{20}$ Indeed, it is the absence of a centralized authority with coercive enforcement power that leads many scholars to believe that "international law," strictly speaking, really isn't "law" at all. ${ }^{21}$

If this view is correct, then the theory that explains first-order legal obligation in terms of coercive enforcement has the advantage of explaining the essential role of coercion in law by linking it to another concept central to law namely, the concept of legal obligation. The central role coercion plays in every conceptually possible legal system is explained by its conceptual role in defining the first-order obligations of citizens. Moreover, it would provide a link between the claim that it is a conceptual truth that first-order legal norms are enforced by the state's police power and the claim that it is a conceptual truth that first-order legal norms define citizen obligations.

In any event, the theory defended here neither assumes nor implies that coercive enforcement is a necessary feature of law. This theory purports to explain legal obligation only in systems, like those most familiar to us, generally backed by coercive enforcement. It does not purport to explain legal obligation in systems where mandatory norms are backed only by generalized social pressure of the sort that typically backs social obligations. Of course, in such systems (which otherwise satisfy the conceptual prerequisites for law), the foregoing analysis suggests that what constitutes such

20 For example, Finnis asks, "Would there be a need for legal authority and regulation in a world in which there was no recalcitrance and hence no need for sanctions?" (NLNR 266).

21 Hart, for example, observes that one good reason for thinking that what we call "international law" is not really law at all is that "there is no centrally organized effective system of sanctions" (CL 4). 
norms as legally obligatory, in part, is that they are backed by generalized social pressure.

This is a virtue, I think, because the jury remains out on the conceptual necessity of formal coercive enforcement mechanisms in law. Though he sometimes characterizes systems lacking formal enforcement as "pre-legal," Hart more frequently characterizes them as being "rudimentary" or "primitive" systems of law (CL 84). ${ }^{22}$ Indeed, Hart generally speaks of such mechanisms as being common but not necessary: "the typical form of legal pressure [supporting legal obligation] may very well be said to consist in such threats [of physical punishment or unpleasant consequences]" (CL 179, 180; emphasis added).

\section{The Binding Force of Obligation}

This theory explains the bindingness of mandatory legal norms in terms of considerations likely to be regarded by subjects as normatively relevant. First, being subject to coercively enforcement is a clear sense in which that norm can plausibly be characterized as being non-optional. Second, the authorization of coercive enforcement mechanisms including the contempt power) is something that is normatively relevant to any rational citizen. This, again, is not to claim that citizens are necessarily motivated to obey the law by a fear of sanctions; rather, the point is merely that rational self-interested citizen are, as descriptive matter, likely to care about avoiding the coercive enforcement power of the state.

One might worry, however, that the sort of reason provided this theory of legal obligation is, as a conceptual matter, the wrong kind of reason. In particular, one might object that this account explains the normative legal obligation in terms of prudential considerations and hence reduces legal reason to first-order prudential reasons. This

22 I am indebted to Scott Shapiro for this point. 
is problematic insofar as one thinks (1) prudential reasons are not the only basic reasons constituting a legal reason and (2) legal reasons are pre-emptive reasons.

As to (1), it seems clear that legal reasons, on a positivist view, being the product of a human artifact manufactured by social processes (i.e., a legal system) would have to be a compound reason reducible to basic reasons. And it is clear that a positivist cannot hold that it is a conceptual truth that a legal reason is partly reducible to a moral reason without violating the Separability Thesis that there are no necessary moral constraints on the content of law. As, we saw above, there is a limited palate of basic reasons to choose from: there seem to be no other kinds of basic reason other than prudential, moral, and possibly aesthetic reasons. And it should be clear that legal reasons are not constituted, even in part, by basic aesthetic reasons if such there be. If legal reasons are compound, the only kind of reason they could be reduced to are prudential reasons.

As to (2), the idea that legal reasons are pre-emptive reasons is contentious. While it is clear that mandatory legal norms are, by the very nature, exclusionary in the sense that they exclude certain justifications for non-performance, this does not, by itself, imply that the reasons created by such norms are pre-emptive in the Razian sense. Given the fact that Razian account of authoritative reasons is contentious, the objection simply begs the question against the account offered here.

\section{The Right Kind of Normativity}

The idea that the authorization of coercive enforcement constitutes a mandatory norm as legally obligatory harmonizes nicely with another important idea concerning legal obligation - namely that there is no prima facie moral reason to obey the law. Most theorists have come to reject not only the idea that the law necessarily gives rise to moral obligations, but also the weaker idea that it is necessarily the 
case that we have a moral reason to obey legal requirements; indeed, many theorists are even skeptical about the idea that law in a legitimate state necessarily gives rise to a moral obligation to obey. If this plausible view is correct, then the fact that a mandatory legal norm creates a legal obligation does not imply that it creates a moral obligation to obey it -or even that there is a prima facie moral reason to obey it.

This harmonizes nicely with the theory of first-order legal obligation defended here. The only reasons for action that are necessarily provided by a legally obligatory norm, if the theory here is correct, are prudential in character. Clearly, first-order legal obligation would be prudentially normative on the story offered here: it is not in the interests of a person, other things being equal, to be subject to the sorts of coercive mechanisms that are used to enforce mandatory legal norms. Equally clearly, first-order legal obligation is not necessarily morally normative on this story: there is nothing in the claim that the state has backed a norm with coercive enforcement mechanisms that would imply that there is even a prima facie moral reason to obey that norm.

This is exactly what we would expect if the prevailing view that law does not necessarily give rise to prima facie moral reasons to obey the law is correct. An analysis of legal obligation that implies we have even a prima facie moral reason to satisfy our legal obligations would be inconsistent with this view. The fact that, on the analysis offered here, legal obligation is not necessarily morally normative is a strong point in its favor.

Nevertheless, it is important to note that legal obligation is, as a conceptual matter, normative on the analysis offered here. Insofar as people have a prima facie prudential reason to avoid having a norm coercively enforced against them, they have a prima facie prudential reason to obey any mandatory legal norm. But this coheres nicely with the prevailing view that it is a conceptual truth that law is norma- 
tive; since mandatory legal norms are at least prudentially normative, they are, a fortiori, normative.

Accordingly, law provides content-independent considerations that a practically rational subject will regard as relevant from the standpoint or prudential rationality or, as it sometimes put, content-independent reasons for action. These reasons need not be conclusive and might be outweighed for the actor by other considerations, but the authorization of coercive enforcement for a valid law always seems to provide some reason for complying with the law's requirements. ${ }^{23}$ Legal obligation is thus, on this analysis, necessarily normative but not necessarily morally normative.

23 See footnote 14 . Norms may become invalid through desuetude. 